\title{
PHYTOTOXIC ANALYSIS OF THE IMPACT OF TRANSMISSION OIL CONTAMINATED SOIL ON GERMINATION AND GROWTH OF OAT (AVENA SATIVA) SEEDLINGS UNDER DIFFERENT SOIL MOISTURE CONDITIONS
}

\author{
O. O. ALONGE, C. C. OGBAGA AND F. M. MAIRAMI \\ (Received 6 April 2017; Revision Accepted 25 May 2017)
}

\begin{abstract}
This study examined the phytotoxic impact of transmission oil pollution on Oat (Aveena sativa) seedlings growing in contaminated soils under 3 different soil moisture conditions of $100 \%$ water saturation, $60 \%$ and $30 \%$ water contents. The synergistic role of the microorganism Pseudomonas putida as a bioremediating agent was also examined.

Experimental soil was treated with transmission oil for up to 12 weeks but seedlings were grown and measured on weeks 1,7 and 12 using derno-podzoluivisolic soil collected from forest reserve of the Russian State Agrarian University. Results showed that seedlings grown on week 7 and 12 germinated better but had variable growth rates. In addition, Pseudomonas putida seemed to improve seedling germination at lower water contents for both weeks. This experiment suggests that Pseudomonas putida may be a good candidate for bioremediation.
\end{abstract}

KEYWORDS: Transmission oil, derno-podzoluivisolic soil, Pseudomonas putida, phytotoxicity, soil moisture.

\section{INTRODUCTION}

The contamination of soils by petroleum hydrocarbon severely hinders plant growth and development, due to alteration of the physical and chemical properties of the soil, as well as the disruption of soil microbial activities (Ekundayo, 2001; Bamidele, 2011; Jain, 2011; Alonge, 2016). The level of petroleum hydrocarbon contamination in the soil directly affects plant growth and development. A high level of petroleum hydrocarbon contamination initially impairs germination of seedlings as a result of the displacement of air and water leading to the development of anaerobic conditions in the soil. In contrast a low level of petroleum hydrocarbon has a positive impact on plant growth and development, as a result of the mineralization of organic compounds by microorganisms, availability of nutrients, moisture, air etc. (Ekundayo, 2001; Ananieva, 2003; Bamidele, 2011; Jain, 2011; Athar, 2016).

Several studies have analyzed the effects of crude oil contamination on plants using various bio-test plants as specimens. These studies focused on the effects of various types of petroleum products on seed germination, plant growth and phytoremediation (Kayode, 2009; Ogbaga, 2016). On the other hand, various soil moisture levels were shown previously to contribute to the detoxification of diesel-contaminated soils (Alonge, 2016).

Oat (Avena sativa) is a $\mathrm{C}_{3}$ crop known to thrive in temperate regions and adapted to wide range of soil types. However, it is sensitive to water deficit with drought being a major limiting factor for its yield (Sanchez-Martin, 2015). There is no known data as regards its growth in transmission oil contaminated soil particularly in Russian specific derno-podzoluivisolic soil. There is also no available data on its seed germination when grown under such soil at different soil moisture levels. It was hypothesized that transmission oil contaminated derno-podzoluivisolic soil would be phytotoxic to oat seedling germination and growth.

Pseudomonas putida is a soil bacterium capable of degrading environmental pollutants and tolerant of organic solvents (Tang, 2011). It has been shown to be useful in bioremediation evidenced in its naphthalenedegrading ability and its adaptability to different habitats and nutritional environments (Gomes, 2005; Molina, 2014). Further, the role of Pseudomonas putida as a bioremediating agent was studied using soil from the central region of Russia. However, there has been no recommendation on the use of the bacterium for bioremediation and detoxification under water deficit.

Thus, the aim of the research was to study the phytotoxic effects of transmission oil contamination on Oats grown under three different levels of soil water contents - $100 \%$ maximum water holding capacity (MWHC), $60 \%$ and $30 \%$ of MWHC.

\section{MATERIALS AND METHODS}

Soil: Mixed samples of the top humic-accumulative

o. O. Alonge, Department of Biological Sciences, Baze University, Abuja, Nigeria.

C. C. Ogbaga, Department of Biological Sciences, Nile University of Nigeria, Abuja, Nigeria.

F. M. Mairami, Department of Biological Sciences, Baze University, Abuja, Nigeria. 
horizon $\left(\mathrm{A}_{1}\right)$, and it's transit horizon $\left(\mathrm{A}_{1} \mathrm{~A}_{2}\right)$ of a loamy, completely podzolized derno-podzoluivisolic soil, collected from Area 4 of the ecological monitoring site, located in the experimental forest reserve of the Russian State Agrarian University - (MTAA named after K.A. Timiryazev) was used (Burinova, 2001) (Table. 1).

Table 1: Summary of the properties of the derno-podzoluivisolic soil (Burinova, 2001)

\begin{tabular}{|l|l|l|l|l|l|l|}
\hline $\begin{array}{l}\text { Topography and location } \\
\text { (coordinates) of the area of } \\
\text { sample collection }\end{array}$ & Horizon & Depth & Corg, \% & $\mathbf{p H}_{\text {H2O }}$ & $\mathbf{p H}_{\mathbf{K C L}}$ & $\begin{array}{l}\mathbf{H}, \mathbf{m g} \text { - } \\
\text { eqv/100g } \\
\text { soil }\end{array}$ \\
\hline $\begin{array}{l}\text { The sample was collected at the } \\
\text { middle of a slightly steep slope } \\
\text { (N55 } 48^{\prime} 59.5^{\prime \prime} \\
\left.\text { E037 } 32^{\prime} 59.4^{\prime \prime}\right)\end{array}$ & $\mathrm{A}_{1}+\mathrm{A}_{1} \mathrm{~A}_{2}$ & $0-28$ & 1,26 & 4,09 & 3,61 & 11,90 \\
\hline
\end{tabular}

Pollutant: Transmission oil, which possessed the following properties: density: $950 \mathrm{~kg} / \mathrm{m}^{3}$, boiling point: $185^{\circ} \mathrm{C}$, freezing point: $-18^{\circ} \mathrm{C}$ was used.

Microorganism: Pseudomonas putida (strain 91-96) was used as the petroleum hydrocarbon degradation agent, Pseudomonas putida used for the experiment was contained in the bio-preparation Pseudomin. The specific strain was first isolated from petroleum hydrocarbon contaminated derno-podzoluivisolic soils, by the department of Microbiology and Immunology of the Russian State Agrarian University - MTAA.

Bio-test Specimen: Oat seeds (Avena sativa) were bought from a market in Moscow, Russia.

\subsection{Methodology}

Soil phytotoxicity test was carried out at regular intervals by bio-testing the Oat (Avena sativa) seedlings (Bamidele, 2011; Jain, 2011; Alonge, 2016; Ogbaga, 2016). The research was performed in the microbiology laboratory of the Russian State Agrarian UniversityMTAA

\subsubsection{Experimental Design}

The soil phytotoxic analysis was performed by directly sowing the Oat seeds into soil taken from research samples undergoing bioremediation (Table. 3). $15 \mathrm{mg} / \mathrm{g}$ of transmission oil was added according to the different experimental variants shown in Table 3 and its degradation evaluated up to 12 weeks. Five pieces of Oat seeds each were sown into Petri dishes containing $20 \mathrm{~g}$ of the derno-podzoluivisolic soil samples according to the experimental scheme (Table 2). Soil Moisture Contents were estimated using the method of Ogbaga and co-workers (Nwachukwu, 2001; Molina, 2014). The plates were incubated for 7 days at room temperature, after which seedling germination (in \%) and growth (in $\mathrm{cm})$ were analyzed. Analyses were performed three times - in the first, seventh and twelfth week of the experiment. The impact of contamination at different soil water levels and in some experiments in addition to the bioremediating agent, Pseudomonas was evaluated (Table 2).

Table 2: Experimental Design

\begin{tabular}{|l|l|l|}
\hline Soil Moisture Content & № of Variant & Soil Sample \\
\hline \multirow{5}{*}{$100 \%$} & 1 & Uncontaminated soil \\
\cline { 2 - 3 } & 2 & Contaminated soil \\
\cline { 2 - 3 } & 3 & Uncontaminated soil + Pseudomonas \\
\cline { 2 - 3 } & 4 & Contaminated soil + Pseudomonas \\
\hline \multirow{5}{*}{$60 \%$} & 5 & Uncontaminated soil \\
\cline { 2 - 3 } & 6 & Untaminated soil \\
\cline { 2 - 3 } & 7 & Contaminated soil + Pseudomonas \\
\cline { 2 - 3 } & 8 & Uncontaminated soil \\
\hline \multirow{5}{*}{$30 \%$} & 9 & Cncontaminated soil + Pseudomonas \\
\cline { 2 - 3 } & 10 & Contaminated soil + Pseudomonas \\
\cline { 2 - 3 } & 11 & \\
\cline { 2 - 3 } & 12 & \\
\hline
\end{tabular}


Table 3: The rate of transmission oil degradation in the mixed samples of the top humic-accumulative horizon $\left(A_{1}\right)$, and transit $\left(A_{1} A_{2}\right)$ horizon of the understudy derno-podzoluivisolic soil

\begin{tabular}{|c|c|c|c|c|c|c|c|}
\hline \multirow[b]{2}{*}{ 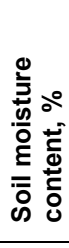 } & \multirow{2}{*}{\multicolumn{2}{|c|}{ Experimental Variants }} & \multirow{2}{*}{ 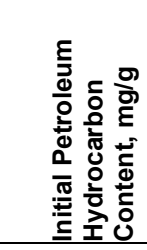 } & \multirow[b]{2}{*}{ 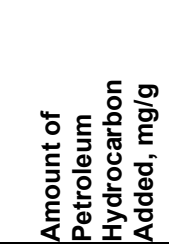 } & \multicolumn{3}{|c|}{$\begin{array}{l}\text { Total Petroleum } \\
\text { Hydrocarbon, } \mathrm{mg} / \mathrm{g}\end{array}$} \\
\hline & & & & & 1 & 8 & 12 \\
\hline \multirow{2}{*}{ 응 } & 1 & Contaminated Soil & \multirow{2}{*}{0.01} & \multirow[b]{2}{*}{15.0} & 2.15 & 0.54 & 0.20 \\
\hline & 2 & Contaminated Soil + Pseudomonas & & & 1.73 & 0.35 & 0.19 \\
\hline \multirow[b]{2}{*}{8} & 3 & Contaminated Soil & \multirow[b]{2}{*}{0.01} & \multirow[b]{2}{*}{15.0} & 9.35 & 2.99 & 0.84 \\
\hline & 4 & Contaminated Soil + Pseudomonas & & & 9.18 & 2.06 & 0.55 \\
\hline \multirow[b]{2}{*}{ প } & 5 & Contaminated Soil & \multirow[b]{2}{*}{0.01} & \multirow[b]{2}{*}{15.0} & 9.54 & 3.92 & 1.72 \\
\hline & 6 & Contaminated Soil + Pseudomonas & & & 9.36 & 3.55 & 1.65 \\
\hline \multicolumn{3}{|c|}{ Approximate Safe Exposure Level } & \multicolumn{2}{|l|}{$4 \mathrm{mg} / \mathrm{g}$} & & & \\
\hline
\end{tabular}

\section{RESULTS}

The phytotoxic analysis of the effect of transmission oil contaminated derno-podzoluivisolic soil on the germination and growth of Oat seedlings is displayed in table 4 below:

Table 4: The phytotoxic effect of transmission oil contaminated derno-podzoluivisolic soil on the growth of oat seedlings under different soil moisture conditions

\begin{tabular}{|c|c|c|c|c|c|c|c|c|}
\hline \multirow{2}{*}{ 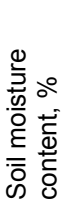 } & \multirow{2}{*}{\multicolumn{2}{|c|}{ Experimental Variants }} & \multicolumn{2}{|l|}{ Week 1} & \multicolumn{2}{|l|}{ Week 7} & \multicolumn{2}{|l|}{ Week 12} \\
\hline & & & Number of & $\begin{array}{l}\text { Maximum } \\
\text { length of }\end{array}$ & Number of & $\begin{array}{l}\text { Maximum } \\
\text { length of }\end{array}$ & Number of & $\begin{array}{l}\text { Maximum } \\
\text { length of }\end{array}$ \\
\hline \multirow[b]{2}{*}{ 음 } & 1 & Contaminated soil & 40 & 6.6 & 100 & 8.0 & 100 & 8.3 \\
\hline & 2 & $\begin{array}{l}\text { Contaminated soil + } \\
\text { Pseudomonas }\end{array}$ & 40 & 6.2 & 100 & 7.1 & 100 & 7.3 \\
\hline \multirow[b]{2}{*}{8} & 3 & Contaminated soil & 40 & 4.0 & 100 & 7.0 & 100 & 8.2 \\
\hline & 4 & $\begin{array}{l}\text { Contaminated soil + } \\
\text { Pseudomonas }\end{array}$ & 60 & 4.0 & 100 & 6.5 & 100 & 8.8 \\
\hline \multirow[b]{2}{*}{ ㅇ } & 5 & Contaminated soil & 0 & - & 60 & 5.5 & 60 & 6.0 \\
\hline & 6 & $\begin{array}{l}\text { Contaminated soil + } \\
\text { Pseudomonas }\end{array}$ & 0 & - & 60 & 4.3 & 60 & 6.3 \\
\hline
\end{tabular}

In the first week of petroleum hydrocarbon application, experimental variants $3,4,5$ and 6 had higher hydrocarbons relative to the control. However, with time, total hydrocarbon degradation occurred such that the values recorded in all experimental variants were below the approximate safe exposure level of $4 \mathrm{mg} / \mathrm{g}$ (Table 3).

Analysis of seedlings grown at $60 \%$ and $30 \%$ soil moisture revealed that with time, both germination and growth improved with the addition of Pseudomonas (Table 4). By week 12, seedlings grown at those water levels with the addition of Pseudomonas tended to grow taller relative to those grown in contaminated soil alone (Table 4). In contrast, control seedlings grown at $100 \%$ water saturation were consistently shorter with the addition of Pseudomonas compared with those grown in contaminated soil alone. However, the number of germinated seedlings improved with or without the addition of Pseudomonas (Table 4).

\section{DISCUSSION}

Depending on the quantity, petroleum hydrocarbon pollution initially impacts negatively on the soil, having toxic effects on plants, inhibiting microbial activities in the soil and degrading the physical and chemical properties of the soil. Gradually the toxic effects reduce due to microbial activities in the soil which capture the petroleum hydrocarbon as a source of energy and food (Berestetskiy, 1971; Ananieva, 2003; Alonge, 2016; Ogbaga, 2016). The low level of total petroleum hydrocarbon concentration after week 1 of the experiment suggests that rapid degradation occurred with time. 
The indigenous microorganisms of the contaminated samples and the inoculated samples with Pseudomonas putida, all actively took part in the biodegradation of the transmission oil in the contaminated soil samples, thereby reducing its toxic effect with time on the oat seedlings. Comparative analysis of the samples with $60 \%$ soil moisture displayed a better outcome in contrast to samples with $30 \%$ soil moisture. This suggests that the level of soil moisture at $60 \%$ may be optimal for intensifying microbial activity in mitigating the toxic effect of transmission oil (Ogbaga, 2014; Ogbaga, 2016).

The phytotoxic effect of transmission oil was especially displayed in the samples with deficient soil moisture $(30 \%)$, where a complete inhibition of oat seedling germination was observed in both samples after the first week of experiment. Over time the toxic effect was partially reduced probably due to the decomposition of transmission oil by the actions of Pseudomonas putida contained in the bio-preparation, and the normal soil micro-biota. Ultimately the percentage of germinated oat seedlings increased, but only up to $60 \%$, and the length of oat seedlings up to 6.3 $\mathrm{cm}$, suggesting that low soil moisture aggravates growth and germination in response to transmission oil contamination.

Under conditions of total soil moisture saturation, the excess availability of water undoubtedly influenced the outcome of oat seedling germination, by diluting the toxic effect of transmission oil, leading to $100 \%$ oat seedling germination in all soil samples.

\section{CONCLUSION}

In summary, analysis of the phytotoxic effect of transmission oil contaminated derno-podzoluivisolic soil on the germination and growth of oat seedlings, have shown a positive impact of the hydrocarbon oxidizing microorganism, Pseudomonas putida. Possible role of the microorganism in the reduction of the toxic effect of transmission oil contaminated derno-podzoluivisolic soil on the growth of the Oat seedlings particularly under water deficit has been shown. It is suggested that $60 \%$ water content could be optimal for soil microbial activities.

Conflict of interest: No conflict of interest declared.

\section{ACKNOWLEDGEMENT}

The authors would like to thank and appreciate the supervisory role and support of Professor Vasenev I.I., and Dr. Selitskaya O.V., of the Russian State Agrarian University-MTAA named after K.A. Timiryazev. Special thanks also to the Bilateral Education Agreement between the Russian and Nigeria government for sponsoring the research.

\section{REFERENCES}

Alonge, O. O., 2016. Analysis of the phytotoxic effects of diesel fuel contaminated derno-podzoluivisolic soils on plants and the impact of biopreparation pseudomin in detoxification under different soil moisture conditions. International Journal of Advanced Biotechnology Research, 6, (3): 370372.

Alonge, O. O., 2016. Bioremediation of transmission oil contaminated derno-podzoluivisolic soil under different soil moisture conditions using Pseudomonas putida. Journal of Tropical Biosciences, 11, 31-36.

Ananieva, N. D., 2003. The microbiological aspects of soil self-purification and stability // Science, 223

Athar, H. U., Ambreen, S., Javed, M., Hina, M., Rasul, S., Zafar, Z. U., Manzoor, H., Ogbaga, C. C., Afzal, M., Al-Qurainy, $F$ and Ashraf, M., 2016. Influence of sublethal crude oil concentration on growth, water relations and photosynthetic capacity of maize (Zea mays L.) plants. Environ Sci Pollut Res. 23, (18): 18320-18331.

Atlas, R. M and Bartha, R., 1992. Hydrocarbon biodegradation and oil spill bioremediation (ed. by K.C. Marshall) // Adv. Microb. Ecol. 12, 287338.

Bamidele, J. F and Igiri, A., 2011. Growth of seashore paspalum (Paspalum vaginatum) in soil contaminated with crude petroleum oil. J. Appl. Sci. Environ. Manage. 15, (2): 303-306.

Berestetskiy, O. A., 1971. Methods for determination of soil toxicity. In Sb.: Microbiological and biochemical studies of soils. Kiev, Vintage 1971 a. - P. 200-245.

Burinova, B. V., 2001. Ecological evaluation of the spatial and temporal variability of the heavy metal content of the soils of the experimental forest reserve of the Russian State Agrarian University - MTAA named after K.A. Timiryazev II. Ph.D. Dissertation synopsis. - Moscow,-25. .

Ekundayo, E. O., Emede, T. O and Osayande, D. I., 2001. Effects of crude oil spillage on growth and yield of maize (Zea mays L.) in soils of Midwestern Nigeria. Plant, Food and Human Nutr. 56:313324.

Gomes, N. C., Kosheleva, I. A., Abraham, W. R and Smalla, K., 2005. Effects of the inoculant strain Pseudomonas putida KT2442 (pNF142) and of naphthalene contamination on the soil bacterial community. FEMS microbiol ecol, 54, (1): 21-33.

Halimov, E. M., Levin, S. V., Guseev, S. V., 1996. Ecological and microbiological aspects of the damaging effect of oil on the properties of soil // Bulletin. Moscow State University. - Ser. 17. Soil Science, - № 2. - P. 59-64.

Jain, P. K., Gupta, V. K., Gaur, R. K., Lowry, M., Jaroli, D. $P$ and Chauhan, U. K., 2011. Bioremediation of Petroleum oil Contaminated Soil and Water. 
Research Journal of Environmental Toxicology, 5: 1-26.

Kayode, J., Oyedeji, A. A and Olowoyo, O., 2009. Evaluation of the effect of pollution with spent lubricant oil on the physical and chemical properties of soil. Pacific J. Sci. Tech. 10, (1): 387-391.

McCown, D. D and Deneke, F. J., 1973. Plant germination and seedling growth as affected by the presence of crude petroleum, in Proc. Symp. Impact of Oil, Resources development of Northern Plant Communities, Inst. Of Arctic Biology, Univ. of Alaska, Fairbanks, Alaska, 4451.

McGill, W. B., 1976. An introduction to field personnel acts of oil spills on soil and some general restoration and clean up procedures. Albert Institute of Petrology. AIP publisher, No. C-76-1.

Methods for measuring seedling germination and root lengths of higher plants the toxic effects of technogenic polluted soils, 2006. FR.1.39.2006.02264 Russian Federal Register.

Molina, L., Udaondo, Z., Duque, E., Fernández, M., Molina-Santiago, C., Roca, A., Porcel, M., de la Torre, J., Segura, A., Plesiat, P and Jeannot, K., 2014. Antibiotic resistance determinants in a Pseudomonas putida strain isolated from a hospital. PLOS ONE, 9(1), p.e81604.

Nwachukwu, S. C. U., 2001. Bioremediation of sterile agricultural soils polluted with crude petroleum by application of the soil bacterium, Pseudomonas putida, with inorganic nutrient supplementations. Curr Microbiol ; 42, (2): 231236.
Ogbaga, C. C., Stepien, P and Johnson, G. N., 2014. Sorghum (Sorghum bicolor) varieties adopt strongly contrating strategies in response to drought. Physiol plant. 152: 389-401

Ogbaga, C. C., Stepien, P., Dyson, B. C., Rattray, N. J., Ellis, D. I., Goodacre, R and Johnson, G. N., 2016. Biochemical analysis of Sorghum Varieties reveal differential responses to drought. PLOS ONE. 11(5): e0154423.

Rowell, M. J., 1977. The effect of crude oil spills on soils. In: The reclamation of agricultural soils after oil spills, J.A.Toogood (editor). Department of Soil Science, University of Alberta, Edmonton. pp 1-33.

Sanchez-Martin, J., Heald, JIM., Kingston-Smith, A., Winters, ANA., Rubiales, D., Sanz, M., Mur, L. A and Prats, E., 2015. A metabolomic study in oats (Avena sativa) highlights a drought tolerance mechanism based upon salicylate signalling pathways and the modulation of carbon, antioxidant and photo-oxidative metabolism. Plant Cell Environ, 38, (7): 1434-1452.

Stankevich, D. S., 2002. Using hydrocarbon oxidizing bacteria of the genus Pseudomonas putida for the bioremediation of oil-contaminated soils. Ph.D. Dissertation. - Moscow, P. 189.

Tang, H., Yu, H., Li, Q., Wang, X., Gai, Z., Yin, G., Su, F., Tao, F., Ma, C and Xu, P., 2011. Genome sequence of Pseudomonas putida strain B6-2, a superdegrader of polycyclic aromatic hydrocarbons and dioxin-like compounds. J.bacteriol, 193, (23): 6789-6790. 